2

3 Mónica A. Silva ${ }^{1,2}$, Miguel Machete ${ }^{1}$, Dália Reis ${ }^{1}$, Marco Santos $^{1}$, Rui Prieto ${ }^{1}$, Carla

4 Dâmaso ${ }^{1}$, João Gil Pereira ${ }^{1}$ and Ricardo S. Santos ${ }^{1}$

5

$6 \quad{ }^{1}$ Departamento de Oceanografia e Pescas da Universidade dos Açores \& Centro do

7 IMAR da Universidade dos Açores, 9901-862 Horta, Portugal

$8 \quad$ E-mail: monica@uac.pt,msilva@whoi.edu

$9 \quad$ Tel: +351292200400

10

11

12

13

14

15

16

17

\section{A review of interactions between cetaceans and fisheries in the Azores}

Dâmaso, João Gil Pereira and Ricardo S. Santos

Fax: +351292200411

(1)

${ }^{2}$ Biology Department, MS\#33, Woods Hole Oceanographic Institution, Woods Hole MA02543, USA

14

\section{ABSTRACT}

1. Interactions between cetaceans and fishing activity in the Archipelago of the Azores were examined using information contained in grey literature and previously unpublished data collected by observer programmes and research projects from 1998 to 2006. Together with a brief description of the economics, gear, fishing effort, and past and ongoing monitoring projects, levels of cetacean bycatch and interference were reported for each major fishery.

2. Cetaceans were present in $7 \%(n=973)$ and interfered in $3 \%(n=452)$ of the fishing events monitored by observers aboard tuna-fishing vessels. Interference resulted in a 
significantly higher proportion of events with zero catches but it was also associated with higher tuna catches.

3. There was a decreasing trend in the proportion of tuna-fishing events with cetacean presence or interference throughout this study, as well as a reduction in the estimates of dolphins captured annually by the whole fleet.

4. Observers reported cetacean depredation in $16 \%$ of the sets for demersal species and in $2 \%$ of the sets for swordfish. Cetacean presence and depredation were associated with higher overall catches and higher catches per unit effort in demersal fisheries. Bottlenose dolphins (Tursiops truncatus) were responsible for most depredation events in demersal fisheries, whereas in the swordfish fishery, depredation was associated with the presence of killer whales (Orcinus orca). There were no reports of cetacean bycatch in these fisheries. There were also no reports of cetaceans interacting in the experimental deep-sea fisheries that were examined.

5. Available data suggests that levels of interaction between cetaceans and Azorean fisheries are generally low and that the economic impact of cetacean interference is probably small. However, for several traditional fisheries there are no accurate data to determine levels of cetacean interaction. We recommend that existing observer programmes be expanded to increase observer coverage of the demersal and swordfish fisheries and allow monitoring of other existing and emerging fisheries.

Keywords: cetacean-fisheries interactions; depredation; bycatch; fisheries; Atlantic Ocean; Azores

\section{INTRODUCTION}


There is evidence of an extensive worldwide interaction between marine mammals and fisheries (Northridge, 1991; Read, 2008). Such interactions may take several forms, but with a few exceptions they are always regarded as potentially harmful to both marine mammals and fishermen (Beddington et al., 1985). By-catch of marine mammals in fishing operations and damage to fishing gear are probably the best documented and most evident part of these interactions (Read, 1996). More recently, increasing attention has been given to the potential competition between marine mammals and fisheries for available food resources (Trites et al., 1997; Kaschner et al., 2001). However, marine mammals are known to interfere with the fishing activity in other ways, namely by removing or damaging fish captured in the gear, frightening fish away or increasing time spent in fishing operations (Wada et al., 1991; Wickens, 1994; Silva et al., 2002; Dalla Rosa and Secchi, 2007; Wise et al., 2007; Brotons et al., 2008). These interactions may cause significant reductions in the catch per unit effort and result in important economic losses to fishermen (Roche et al., 2007; Brotons et al., 2008), which, in turn, may lead to retaliatory measures against marine mammals or calls for extreme mitigation measures to avoid interactions. Frequently, however, fishermen have the wrong perception and the real impact of marine mammal interaction may be small (Silva et al., 2002; Prieto et al., 2005; Wise et al., 2007). Thus, understanding the interaction between marine mammals and fisheries and assessing its frequency and impact is crucial to inform fishermen, as well as to assist management efforts.

Silva et al. (2002) studied the interaction between cetaceans and the tuna fishery in the Azores using three-years of data collected by observers. The authors examined the spatial and temporal patterns of occurrence of cetaceans in the fishery, evaluated their impact, and estimated incidental capture of cetaceans. To our knowledge, this is 
the only published work on cetacean-fisheries interactions in the Azores and so far there have been no attempts to document the operational or ecological interactions between cetaceans and other fisheries.

Since 1998, the Department of Oceanography and Fisheries of the University of the Azores (DOP/UAç) has monitored several fishing operations in the Archipelago within the scope of monitoring programmes or research projects. Although most of these projects were not specifically designed to monitor cetacean bycatch or cetaceanfishery interactions, all projects collected data from which some information on both aspects can be obtained.

The objective of this study is to document the interaction between cetaceans and the fishing activity in the Azores, using information and data collected from 1998 to 2006. In addition to gathering and reviewing information contained in grey literature, new data collected by observer programmes and research projects are analysed. The paper provides a brief overview of the major fisheries, focusing on the economics, target species, fishing area, gear, operations, fishing effort, past and ongoing monitoring projects, data collection methods and level of observer coverage (when available). Finally, interactions between cetaceans and each fishery are documented. When available, cetacean incidental capture and the effects of the presence of cetaceans in terms of operational disturbance and catch losses to the fishery are reported.

\section{THE AZORES}

The Archipelago of the Azores (Portugal) is located between $37^{\circ}$ and $41^{\circ} \mathrm{N}$, and $25^{\circ}$ and $31^{\circ} \mathrm{W}$, about $1500 \mathrm{~km}$ west of Lisbon (Figure 1). It consists of nine volcanic islands divided into three groups, extending more than $600 \mathrm{~km}$ along a north-west- 
south-east trend and crossing the Mid-Atlantic Ridge. The Exclusive Economic Zone (EEZ) of the Azores covers $954449 \mathrm{~km}^{2}$ and has an average depth of $3000 \mathrm{~m}$. Less than $1 \%$ of the EEZ has depths $<600 \mathrm{~m}$ (includes the narrow shelves of the islands, seamounts and banks), about $1.6 \%$ of the area has water depths between $600 \mathrm{~m}$ and $1000 \mathrm{~m}$, and $6 \%$ between $1000 \mathrm{~m}$ and $1500 \mathrm{~m}$. Thus, fishing grounds are rare, small and scattered, which has significant implications to the fisheries (Martins, 1986).

\section{DATA SOURCES}

For the most part, data presented in this work have not been published. Information on historical landings, fishing gear and operations, fishing effort and observer coverage was obtained from data collected by observer programmes, internal unpublished reports, or student's monographs. Information on recent landings was retrieved from the official annual statistics compiled by the Fisheries Directorate of the Azorean Regional Government or by the Portuguese National Institute of Statistics. Data on cetacean presence and interactions were retrieved from databases maintained by the authors or collated from reports. With the exception of results taken from Prieto et al. (2005) and Catarino (2006), we always had access to the raw data on the interaction of cetaceans with the fisheries.

Despite efforts to standardize this review, the quality and quantity of information presented for each fishery varied considerably. Some fisheries have been better documented than others, especially in relation to the estimation of fishing effort and interactions with cetaceans. In a few cases there was no accurate or updated information on landings and fishing effort, which prevented the estimation of observer coverage. A 
summary of the information used to estimate fishing effort and document cetacean interactions in each fishery is presented in Table 1.

\section{AZOREAN FISHERIES}

Fishing activity has an important socio-economic impact in the Archipelago of the Azores. In 2006, Azorean fisheries landed 11860 tonnes (t), with a gross revenue of about 32 million euros. Within a national context, however, it is considered a small scale fishery contributing to less than $10 \%$ of the Portuguese total landings (INE, 2007). According to the official statistics, in 2006 the Azorean fishing fleet consisted of 735 vessels, although more than $15 \%$ of the vessels did not apply for fishing licences. The fleet is mainly artisanal, with $85 \%$ of the fleet composed of small open or close-deck boats under $12 \mathrm{~m}$ long. The remainder of the fleet comprised medium (12-17 $\mathrm{m})$ to large (>17 m) longliners and tuna-fishing vessels (17-30 m) (INE, 2007).

The fishing regime of the fleet changes considerably between and within years, and even on a daily basis. Most of the boats have licences to operate several types of fishing gear and shift between gears and fisheries depending on the season and variations in the distribution and abundance of target species. This is especially true for small open-deck boats that practise a multispecific fishery and frequently use two or three different types of gear during a daily fishing trip. Of the 613 boats that received a fishing licence in 2006 , over $80 \%$ were issued a permit to use between three and five different gears and less than $5 \%$ requested a permit for a single gear. Moreover, the fisheries are interrelated because the tuna, demersal and swordfish fisheries also capture small pelagic fishes to use as bait (Santos et al., 1995) and fishermen move between different fisheries. On the other hand, vessels often request more licences than they end 
up using. The number of licences issued per se is, therefore, a poor indicator of the fishing effort of each fishery.

There are four main fisheries in the Azores: $i$ ) a fishery for small pelagics (Trachurus picturatus, Scomber japonicus, Sardina pilchardus) conducted with opendeck boats using small seine nets, dipnets and liftnets; ii) a seasonal pole-and-line tuna fishery; iii) a multispecific demersal fishery that uses handlines and bottom longlines operated from open-deck and small to large cabin vessels; and $i v$ ) a swordfish (Xiphias gladius) fishery mostly undertaken by large cabin vessels using surface longlines (Menezes et al., 2002). These fisheries will be described in more detail below.

There is a small coastal bottom-set gillnet fishery that catches a variety of pelagic and benthic fish species. The use of bottom-set gillnets is limited to an area $<500 \mathrm{~m}$ from the coastline and to depths $<30 \mathrm{~m}$. Maximum length of bottom-set gillnets allowed per boat is $500 \mathrm{~m}$, soak time must be $<12$ hours and maximum height of the panel is $10 \mathrm{~m}$. The exploitation of cephalopods and crustaceans is a small-scale, mostly seasonal activity carried out by snorkel divers and hand-pickers, or using bottom traps, iron traps and jigs. Purse seine nets for tuna, trammel nets, drift gillnets, driftnets, bottom trawling and other deep-sea nets are banned from the Azorean EEZ.

\section{SYNOPSIS OF FISHERIES}

\section{TUNA FISHERY}

The tuna fishery is one of the most important fisheries in the Azores. In 2006, $6007 \mathrm{t}$ of tuna were caught in the Azores, which accounted for nearly $50 \%$ of total landings and for $14 \%$ of the economic revenue of the fishing activity in the region (INE, 2007). Yet, the importance of this fishery to the total catch is highly variable from year 
to year, possibly due to changes in tuna abundance and in migration routes (Morato et al., 2001). Five species of tuna are captured in the Azores: bigeye (Thunnus obesus), skipjack (Katsuwonnus pelamis), albacore (T. alalunga), yellowfin (T. albacares) and blue fin (T. thynnus). The former two species constitute the main basis of the fishery, accounting for $95 \%$ of total tuna landings in weight (Dâmaso, 2007). The tuna fishing generally concentrates around the islands, especially around the central and eastern groups of the archipelago, and around offshore seamounts (Silva et al., 2002; Dâmaso, 2007; Morato et al., 2008).

All the tuna fishing vessels operating in the Azores use pole-and-line, usually with live bait and water spray. The fishery lasts from April to October, the period when the tuna migrate to or through the region. A fishing trip lasts on average 5-6 days (Silva et al., 2002). The fishing activity starts in the early morning, with boats searching for tuna schools with binoculars and using seabirds or floating objects as sighting cues. Upon encountering a school, the water spray is activated and the live bait is thrown into the water to attract the tunas. Small pelagic fishes may also be used to bait the hooks (Dâmaso, 2007). The number of fishing events per day varies greatly depending on the tuna abundance and size of the schools encountered, ranging from 1 to 15 (mean $=3.1$, $\mathrm{SD}=2.1$ ) (Silva et al., 2002). The duration of a fishing event and the number of fishing poles (or lines) used were found to be highly variable and poorly correlated to the total tuna caught (Silva et al., 2002). Successful fishing events may last up to 16 hours but the average duration is about 25 minutes.

Fishing effort 
As a result of variations in tuna abundance, there were huge annual and monthly variations in the number of fishing vessels and trips, and in the amount of tuna caught. In the period 1998-2006, the number of operating vessels per month varied from 5 to 28. Detailed information on fishing trips is only available for the period 1998-2000. During this time, the number of trips per month ranged from 6 to 129, with an average of 80 trips (Silva et al., 2002). Annual landings for the tuna fleet during the study period ranged from $1135 \mathrm{t}$ in 2001 to $5400 \mathrm{t}$ in 1998 (Table 2).

Associated with the tuna-fishery there is a fishery for small pelagics which is conducted mostly at night in the vicinity of the islands or around seamounts using small purse-seine nets. Blue jack mackerel (T. picturatus) are caught with nets that are $250 \mathrm{~m}$ long and 10-15 $\mathrm{m}$ in height with a mesh size of $30-40 \mathrm{~mm}$. Purse-seine nets for juvenile of the year blackspot seabream (Pagellus bogaraveo) are slightly smaller: $15 \mathrm{~m}$ long and $10 \mathrm{~m}$ high, with a mesh size of 10-15 mm (Pinho et al., 1995). Information about this fishery is scarce because there are no landings. Based on data collected by observers aboard tuna vessels it has been estimated that the fishery may take around 200 t of bait fish each year (Morato et al., 2001).

\section{Monitoring}

Azorean Fisheries Observer Programme (POPA)

POPA was created in 1998 to guarantee the "dolphin safe" certification to the tuna fishery and its products (Machete and Santos, 2007). POPA is responsible for placing observers aboard tuna vessels aiming to achieve a minimum of $50 \%$ coverage of the fleet. This level of coverage was established for logistical and budgetary reasons. 
POPA also monitors other fisheries, especially all experimental fisheries in the region, although with lower observer coverage.

A complete description of methods and data collection procedures can be found elsewhere (Silva et al., 2002; Machete and Santos, 2007). Contracted observers receive intensive training on fishing gear and operations, identification of tuna, cetacean, seabird and turtle species. Observers are required to monitor all fishing events, including bait fishing, and landings. Cetaceans are considered to be present during a fishing event if at least one individual is seen $<50 \mathrm{~m}$ from the target tuna school. In this case, the species, number of individuals, behaviour and its impact on fishing activity are recorded. Cetaceans are considered to interfere with the fishing when they frighten and sink the tuna school, compete with the tunas by feeding on the live bait, or both. Observers also record if there was incidental or direct take of cetaceans.

Observer coverage, defined as tuna landed by vessels with observers divided by tuna landed by the whole fleet, varied between years, from a minimum of $32 \%$ in 2003 to $67 \%$ in 1999 (Table 2).

\section{Interactions with cetaceans}

From 1998 to 2006, 1526 fishing trips were monitored, during which 14851 tuna fishing events were recorded. Overall, cetaceans were present in 973 (7\%) fishing events. Thirteen cetacean species were recorded in the vicinity of the boats when these were fishing. Common dolphins (Delphinus delphis) accounted for almost $73 \%$ of the occurrences, followed by Atlantic spotted dolphins (Stenella frontalis) (14\%), bottlenose dolphins (Tursiops truncatus) (7\%), sei whales (Balaenoptera borealis) 
(1\%), Risso's dolphins (Grampus griseus) (1\%), fin whales (Balaenoptera physalus) $(1 \%)$, with the remaining species being recorded only once or twice.

When present, cetaceans interfered with the fishing activity on less than half the times $(\mathrm{n}=452)$. Common dolphins were responsible for most of the observed interferences, followed by Atlantic spotted dolphins and bottlenose dolphins (Table 3). The most common types of interference were: tuna schools sank (47\%), cetaceans competed with tunas for the live bait (38\%) and both situations occurred (14\%). On average, fishing events carried out in the presence of cetaceans lasted 15 min longer than events without cetaceans (Dâmaso, 2007). There was a significantly higher proportion of fishing events with zero catches when cetaceans were seen interfering with the fishery $\left(\chi^{2}=5.129, \mathrm{df}=1, P<0.024\right)$. In $8 \%$ of the fishing events carried out with cetacean interference there was no catch, whereas when they were present but did not interfere only $4 \%$ of the events were unsuccessful. In spite of this, mean weight of total tuna caught in fishing events without cetaceans $(763.8 \pm 16.1 \mathrm{~kg})$ was $20 \%$ lower than in events with cetacean interference $(909.3 \pm 87.3 \mathrm{~kg})$, and $33 \%$ lower than in events when cetaceans were present but did not interfere $(1013.3 \pm 79.0 \mathrm{~kg})\left(F_{(2,14964)}=\right.$ $5.954, P=0.003)$.

There was a significant decreasing trend from 1999 to 2006 in the proportion of fishing events with cetaceans $\left(\chi^{2}\right.$ for trend $=206.972$, df $\left.=1, P<0.001\right)$ and with cetacean interference $\left(\chi^{2}\right.$ for trend $=4.124$, df $\left.=1, P<0.025\right)$, with much higher proportions in 1998 and 1999 (Figure 2). There was a strong positive correlation between proportion of events with cetaceans and proportion of cetacean interference (Spearman's rank correlation $R=0.950, \mathrm{P}<0.0001, \mathrm{n}=9$ ), suggesting that cetacean 
presence in the vicinity of the fishing activity may serve as a good proxy for the probability of interference.

From 1998 to 2006, 59 dolphins were incidentally hooked, of which 48 were common dolphins, nine Atlantic spotted dolphins, one bottlenose dolphin and one unidentified small dolphin (Table 2). All the animals were released alive and apparently unharmed by cutting the fishing line. More than $80 \%$ of these incidents occurred in the first three years of the programme and in two consecutive years (2003-2004) there were no reports of cetaceans captured.

Although tuna landed per boat is probably not the best estimate of fishing effort, it is the only statistics available for the entire tuna fleet in the Azores, and no data on the number of fishing events exist in the official records. Therefore, Silva et al. (2002) used total tuna landed per trip as a measure of the fishing effort of the whole fleet to estimate a capture rate of cetaceans from 1998 to 2000 . The same method was used in this study to estimate the number of cetaceans captured by the tuna fleet for the following years. The capture rates were calculated by year as the sum of the cetaceans caught divided by the sum of the observed tonnage of tuna landed per trip. The estimated total number of cetaceans captured per year was then calculated as the observed capture rate multiplied by total tonnage of tuna landed by the fishery in that year. Confidence limits for the total estimated capture were calculated using the formulae given by Cochran (1977) for ratio estimators. According to the estimates obtained, from 2001 to 2006, fewer than four dolphins were captured per year by the tuna fleet, with the exception of 2005, in which the number of dolphins captured may have reached 11 individuals (Table 2).

Between 1998 and 2006, cetaceans interfered with the fishery for small pelagic fish species in $1.6 \%(n=44)$ of the 2670 observed events. Common dolphins were 
responsible for nearly all the interactions. There was no mortality of cetaceans associated with this fishery.

\section{DEMERSAL FISHERIES}

Catches of demersal fisheries usually do not exceed $5000 \mathrm{t}$ per year. Economically, however, these are the most important fisheries in the Azores, contributing $68 \%$ of total earnings from fisheries (about 22 million euros) (INE, 2007). More than 20 species are caught together in significant amounts, the most important being wreckfish (Polyprion americanus), blackspot seabream, common seabream (Pagrus pagrus), bluemouth rockfish (Helicolenus dactylopterus), splendid alfonsino (Beryx splendens), alfonsino (B. decadactylus), conger eel (Conger conger), axillary seabream (Pagellus acarne), and forkbeard (Phycis phycis) (Santos et al., 1995; Menezes, 2003). The fishery is distributed throughout the Azorean EEZ, around the islands, scattered offshore banks and seamounts. About $70 \%$ of the catches are made between $300 \mathrm{~m}$ and $500 \mathrm{~m}$ depth (Menezes et al., 2002). Small and medium cabin boats are responsible for $80 \%$ of the landings of demersal species.

Demersal fisheries use two types of fishing gear: handlines, a term used to designate a wide variety of hook gears that are hand-operated, and bottom longlines. Handlines vary in size and number of hooks (ranging from 1-100), and depending on the target species may use different baits and fish at different depths. Bottom longlines consist of a mainline of nylon monofilament to which branchlines with hooks are attached at a fixed distance. The gear is set from four-sided skates with about 30 hooks. On average 12 skates gear length cover approximately $1.8 \mathrm{~km}$ (Menezes, 2003). 
Longlines are set before dawn and hauled 1-2 hours later. Duration of fishing trips ranges from one day to three weeks, depending on the size of the boats.

\section{Fishing effort}

Estimating the effort of this fishery is difficult, given the characteristics of the boats, the diversity of gears used and the fact that boats frequently shift between fisheries and gears. In addition, open-deck boats that constitute a significant part of the fleet do not keep logbooks. Over 90\% of the boats fishing in the Azores in 2006 were licensed to use handlines and more than $60 \%$ received a licence for bottom longlines. This means that most of the Azorean fleet can target demersal species, even though it may not be their primary fishery.

The estimated fishing effort increased from 1.5 million hooks in 1987 to 13 million hooks in 1994, whereas capture rates decreased from $0.08 \mathrm{~kg} / \mathrm{hook}$ to 0.03 $\mathrm{kg} / \mathrm{hook}$ (Menezes, 1996). Since then, fishing effort is around 60 million hooks (Pinho, 2003). From 1987 to 1999 , landings of demersal species varied between $1200 \mathrm{t}$ and approximately 2900 t. After 2000, catches seem to have slightly increased, usually ranging from $3000 \mathrm{t}$ to $4200 \mathrm{t}$.

\section{Monitoring}

National Programme for the Collection of Data in the Fisheries Sector (NPCD)

European Council Regulation (EC) 1543/2000 established a Community framework for the collection and management of the data needed to implement the Common Fisheries Policy. Observers are placed onboard fishing vessels to monitor the fishing operation and to record the geographic position and depth of every set, number 
and size of hooks used, soak time of the gear, and fish species captured and discarded. In 2004, the programme began collecting information on the presence and interaction of cetaceans in the fishing activity. Observers recorded species, number of individuals and behaviour of cetaceans, and depredation on catches.

From 2004 to 2006, the programme monitored all the components of the fishery but focused mainly on the small and medium cabin boats. Twenty-nine different boats were monitored in three years: five large cabin boats, 14 medium, and the remaining boats were either open or cabin-decks $<12 \mathrm{~m}$. One of the boats monitored used handlines, whereas all other boats used bottom longlines. Observer coverage, calculated in terms of percentage of observed landings, ranged from $0.3 \%$ to $1.0 \%$ (Table 4 ).

\section{Short-term projects}

In addition to data collected by the community observation programme, between August and September 2004, four commercial boats (two open-deck and two small cabin-deck boats) were monitored by one observer to collect data on bycatch rates of demersal fisheries (Catarino, 2006). Overall, 99,000 hooks in 13 bottom longline sets were observed.

Between May 2002 and August 2004, the fishing trips of a $9 \mathrm{~m}$ cabin-boat were monitored to investigate cetacean interactions with the handline segment of the fishery (Prieto et al., 2005). The fishing gear used was composed of baited round hooks attached to $1.1 \mathrm{~m}$ gangions spaced every $1.2 \mathrm{~m}$ along a monofilament leader connected to a steel wire that runs to the surface. The number of hooks in one set varied between 30 and 60 . Data were collected by the captain of the boat and included information about fishing effort, captured species, as well as presence of cetaceans in the vicinity of 
the vessel and detected interactions. Interaction was defined as occasions when fishermen could feel hooked fish being taken from the line. In all, 156 fishing trips were conducted during 39 months of the study.

\section{Interactions with cetaceans}

According to data from the NPCD observer programme, cetaceans were sighted around the fishing gear during hauling in $31 \%(n=83)$ of the sets observed in the three years, but this percentage decreased significantly from 2004 to $2006\left(\chi^{2}\right.$ for trend $=$ 14.936, $\mathrm{df}=1, P<0.001)$ (Table 5). There was also a noticeable drop in the percentage of fishing sets in which cetaceans were reported to interfere with the fishing activity. Cetacean interference appeared to be restricted to depredation. Depredation includes the cases in which the whole fish was removed from the hook plus the cases when dolphins partially consumed and damaged the fish. Depredation was noted in $25 \%, 16 \%$ and $2 \%$ of the sets observed in 2004, 2005 and 2006, respectively (Table 5). Both cetacean presence and depredation were independent from the type of gear used $\left(\chi^{2}=9.285, \mathrm{df}=\right.$ $6, P=0.158)$

Three species of cetaceans were observed in the vicinity of the fishery: bottlenose dolphins $(n=68)$, common dolphins $(n=10)$ and Risso's dolphins $(n=1)$. On five occasions the species was not identified. Bottlenose dolphins were responsible for all the depredation cases (Table 3).

To investigate if the presence and interference of cetaceans had any effect on the outcome of the fishing set, we compared total weight of fish caught per set between sets with and without cetaceans and with cetacean depredation. Sets with cetacean depredation yielded significantly higher catches $(521.9 \pm 54.8 \mathrm{~kg})$ than sets in which 
cetaceans did not interfere $(390.1 \pm 44.5 \mathrm{~kg})$ or sets without cetaceans $(320.8 \pm 25.9 \mathrm{~kg})$ $\left(F_{(2,268)}=5.652, P=0.004\right)$. In addition, the catch per unit effort (calculated as total weight of fish caught divided by the number of hooks used) was significantly higher in sets with depredation $(6.3 \pm 0.7 \mathrm{~kg} / \mathrm{hook})$, when compared to sets without depredation $(4.5 \pm 0.7 \mathrm{~kg} /$ hook $)$ and sets without cetaceans $(3.8 \pm 0.3 \mathrm{~kg} /$ hook $)\left(F_{(2,268)}=5.727, P=\right.$ $0.004)$.

In the three years, there were no reports of bycatch of cetaceans.

\section{Short-term projects}

Between August and September 2004, bottlenose dolphins were observed in the vicinity of the gear in $10(77 \%)$ of the 13 sets, and in two (15\%) sets dolphins were seen stealing fish from the hooks (Catarino, 2006). Although it is difficult to quantify catch losses due to the interference of cetaceans, rates of fish depredation were high. Depredation was reported in $19 \%$ of the sets: in $11 \%$ only the head of the fish was left on the hook and in $8 \%$ (in number and weight) fish were damaged and could not be marketed (Catarino, 2006).

Prieto et al. (2005) reported lower levels of interaction with the handline segment of the fishery. According to these authors, bottlenose dolphins and common dolphins were detected near the fishing boat on 13 and 10 occasions, respectively, which represented $15 \%$ of total fishing events. However, interference with the fishery was reported only on three occasions (12\%), always during hauling. On two occasions bottlenose dolphins were observed removing blackspot seabream from the hooks, and on the other occasion, common dolphins were observed removing mackerel (Table 3) (Prieto et al., 2005). 


\section{SWORDFISH FISHERY}

In 2006, nearly $133 \mathrm{t}$ of swordfish were landed in Azorean fishing harbours, yielding around 827000 euros. The fishery targets swordfish from May/June to December and shifts to the blue shark (Prionace glauca) during the rest of the year, when the swordfish are less abundant. Reported captures of blue shark have increased considerably throughout the years and at present represent between $22 \%$ and $86 \%$ of total catches (in number) of this fishery. Small and medium cabin-deck boats usually operate around the islands and over the fishing banks (Silva, 2000). The large cabindeck boats $(>25 \mathrm{~m})$ operate all year-round but extend their fishing grounds outside the Azorean EEZ in the winter months (Silva, 2000). There is also an important fleet from mainland Portugal and Spain fishing for swordfish in the Azorean EEZ but this fleet hardly ever lands its catch in the Azores.

The surface longline gear consists of a mainline to which branchlines with hooks are sequentially attached at a fixed distance. The number of hooks per set varies between 800 and 2500, depending on the type of longline used by each component of the fleet. One longline set is carried out per day. Longlines are set at dusk and stay in the water overnight, being hauled at dawn. The gear is set between $15 \mathrm{~m}$ and $50 \mathrm{~m}$ depth. Swordfish are also captured in small amounts by bottom longlines used in demersal fisheries.

\section{Fishing effort}

Using the average number of sets per month, the number of hooks per set and the duration of trips given by Simões (1995), together with the number of licences 
issued for each component of the fleet, we roughly estimate the fishing effort for the whole fleet as 11056 sets and $193 \times 10^{5}$ hooks deployed per year.

\section{Monitoring}

In 1998, the University of the Azores and the University of Florida launched a monitoring programme to determine sea turtle bycatch rates and to conduct experiments to assess the effects of longline gear modification on these rates (Bolten et al., 2000). In 1998, a single observer was placed on board a commercial longline vessel. From 2000 to 2004, between two and three observers were placed on a commercial longliner hired to carry out the experiment. Throughout the years, different shapes and sizes of hooks were tested although the fishing operation and gear used were always similar to the ones used in typical commercial fishing operations (Ferreira et al., 2010). Observers collected data on fishing effort, species and number of fish caught, bycatch and depredation on catches. They also recorded whether there were cetaceans or sea turtles in the vicinity of the gear when it was being set or hauled.

Observers onboard did not record the weight of fish caught and they were not present when the boat landed the fish. Thus observation effort could not be measured as percentage of observed landings. Instead, the number of observed sets and hooks were compared with those estimated for the swordfish fleet. On average, the project monitored approximately $0.6 \%$ of the sets and $0.5 \%$ of the hooks deployed by the Azorean swordfish fleet per year.

\section{Interactions with cetaceans}


Cetaceans were recorded in the vicinity of the longline gear 20 times, which represented $5 \%$ of all the sets observed (Table 6). On all but two occasions, cetaceans were present when the gear was being hauled. Bottlenose dolphins were seen three times, Risso's dolphins and killer whales (Orcinus orca) were seen two times each, common dolphins, Atlantic spotted dolphins, pilot whales (Globicephala sp.), false killer whales (Pseudorca crassidens) and sperm whales (Physeter macrocephalus) were recorded once and on the remaining occasions the species was not identified.

Cetaceans were responsible for damage to the fish captured in three $(<1 \%)$ sets (Table 6). In all cases, hooked fishes (always blue sharks) were eviscerated and the liver and pectoral fins were eaten, a type of damage consistent with the kind of mutilation resultant from attacks of killer whales or false killer whales. On one occasion when 17 blue sharks were eviscerated, killer whales were seen near the gear when it was being hauled and on three other hauls when cetaceans were present, the observers recorded damage to fish captured but these seemed to have been caused by sharks.

No cetaceans were captured in any of the observed hauls.

\section{OTHER FISHERIES MONITORED}

The black scabbard fish (Aphanopus carbo) is a very specialized fishery that takes place in deep waters $(1000-2000 \mathrm{~m})$, using drifting bottom longlines (Morato et al., 2001; Machete et al., 2010). After 1999, boats from Madeira started to fish for black scabbard in the Azorean EEZ but most of the vessels land their catch in Madeira. In 2004, landings in the Azores were less than $2 \mathrm{t}$, in the following year landings increased to $323 \mathrm{t}$ and dropped again to $55 \mathrm{t}$ in 2006. Between 1999 and 2005, POPA placed observers aboard six commercial fishing boats, five of which were from Madeira. 
Although it was not possible to obtain information on fishing effort for this fishery, and therefore quantify observer coverage, there were no reports of cetacean capture, presence or interference in the 240 sets that were observed in five years.

Melo and Menezes (2002) report on the results of a experimental trawl fishery directed at orange roughy (Hoplostethus atlanticus) conducted in April-June 2001 and December 2001-January 2002 around two seamounts within the Azorean EEZ. Two observers monitored the fishing experiment, during which 246 hauls were conducted. Although this fishery generates considerable amounts of bycatch, there were no records of cetaceans captured in the experiment.

In 2003 and 2004, one professional fishing boat conducted a fishing experiment directed at the deepwater crab (Chaceon affinis). The fishery occurred at 600-900 m depth, using baited traps (similar to the ones used for lobsters). Observers onboard monitored the entire fishing operation and recorded information on fishing effort, catches and bycatches. Overall, 200 fishing sets were carried out in a five-month period in 2003 and in one month in 2004. There were no reports of cetacean capture, presence or interference in this fishery. Moreover, no gear was lost during the experiment, which often happens when cetaceans get entangled in the gear and drag it away from the fishing site.

In November 2006, POPA monitored a fishing experiment conducted by a professional fishing vessel directed at the deep-water pandalid shrimp (Plesionika edwardsii), using traps in groups. There were no reports of cetacean capture, presence or interference in the 23 sets conducted during the experiment.

In July 2009, DOP/UAç began monitoring the squid jig fishery through interview surveys to fishermen and by placing observers onboard fishing boats, after 
receiving complaints of cetacean depredation. The monitoring programme is still in its infancy and data on cetacean interactions are preliminary and do not allow drawing any conclusions, so this fishery will not be considered further here.

\section{DISCUSSION}

Cetaceans interacted with several fisheries studied but the frequency, effect and magnitude of the interaction varied with the fishery. Levels of interaction between cetaceans and the tuna fishery were low and for the majority of species encounters with actively fishing vessels were rare and seemed to be only casual. In general, the frequency of occurrence of each cetacean species in the fishery is consistent with its known relative abundance in the region (Silva et al., 2003). Common dolphins, Atlantic spotted dolphins and bottlenose dolphins were responsible for most of the presences and nearly all the cases of interference.

The small number of interference cases observed does not support the widespread notion among fishermen that small dolphins are harmful to the tuna fishery. Although occasionally dolphins frighten smaller tunas and increase the proportion of fishing events with no catches and the time spent in fishing operations, these events are outnumbered by those in which the presence and interference of dolphins is associated with higher tuna catches. These results are in agreement with previous findings that showed that fishing events with cetaceans were associated with higher catches per unit effort (Silva et al., 2002) and tunas of larger body sizes (Dâmaso, 2007). These findings suggest the existence of an association between these species of dolphins and large tunas, similar to what was reported in other geographic areas (Allen, 1985). In the Azores, common dolphins and bigeye tunas account for over $70 \%$ of the associations 
observed, whereas Atlantic spotted dolphins and bottlenose dolphins seem to associate more frequently with skipjack (Dâmaso, 2007).

The tuna fishery in the Azores shows extremely low rates of capture of cetaceans and no incidental mortality was reported during nine years of monitoring. Although this is not surprising given the methods and gear used in this fishery, it certainly constitutes an exceptional case of a commercial tuna fishery that does not involve significant mortality levels of cetaceans (Northridge, 1991). Moreover, capture rates have decreased considerably since the beginning of the monitoring programme, although the reasons for this remain unknown.

Conversely to what occurs in the tuna fishery, the interaction between cetaceans and demersal and swordfish fisheries is clearly negative to the fisheries, although in both cases the economic impact is probably low. Preliminary results of the National Programme for the Collection of Data in the Fisheries Sector, as well as of short-term projects, suggest cetaceans interact frequently with demersal fishing operations. Given the characteristics of the hook gears employed, the likelihood of incidental capture should be small and in fact there were no reports of cetacean mortality in three years of monitoring. Instead, the interaction seems to be mainly detrimental to the fishery, with dolphins, especially bottlenose dolphins, removing or damaging fish caught. Estimating the amount of fish removed by dolphins is difficult, unless underwater cameras are deployed around the fishing gear. It is possible, however, to quantify damage to the fish and preliminary observations indicate that damaged fish may represent up to $4 \%$ in weight of total fish caught per fishing trip (Constantino, 2006). However, this author also showed that damage to the fish seemed to result primarily from careless manipulation by fishermen and not from depredation by dolphins or any other species. 
Interestingly, demersal sets with cetacean depredation not only were related to significantly higher catches but also recorded higher catches per unit effort. Sets with cetaceans also recorded higher yields and catches per unit effort than sets without cetaceans. Although there are no data to confirm this, we suggest that dolphins are more attracted to fishing sets with large numbers of hooked fish or when larger species or individuals are caught. It could be argued that fishing sets with higher catches were associated with dolphin presence and interference simply because dolphins occur and forage in areas where fish abundance is higher. However, observers and fishermen reported that on most occasions, dolphins arrived at the fishing site after the boat, which suggests that dolphin interaction is not opportunistic but is influenced by the activity and behaviour of fishing boats.

Longlines are used in many fisheries around the world and are frequently associated with high bycatch rates of various species of seabirds, sea turtles, sharks and billfishes (Hall et al., 2000; Read, 2008). Several species of cetaceans are also known to interact with longline gears, which often results in serious injury and mortality of the individuals involved (Dalla Rosa and Secchi, 2007; Garrison, 2007). There were no records of incidental capture of cetaceans in the Azorean longline fishery monitored in this study. However, observers placed onboard a Spanish longliner fishing west of the Azores reported two false killer whales taken in 56 monitored sets (Hernandez-Milian et $a l ., 2008)$. Thus, further investigation is necessary to estimate bycatch rates of cetaceans in the longline fishery operating in the region.

In this type of fishery where the gear stays underwater overnight, presence of cetaceans can only be recorded when the gear is being set or hauled. Consequently, levels of cetacean presence and interaction reported may be underestimated. In spite of 
this, available data suggests that cetacean depredation in the longline fishery is not frequent, affecting less than one percent of the observed sets. The fish species and type of damage suggest that either killer whales or false killer whales were responsible for all depredation events recorded. Presence of false killer whales was never associated with depredation but killer whales were seen near the gear in one of the depredated sets. Given that both species show low relative abundance in the region (Silva et al., 2003), encounters with fishing operations should be rare and we expect the economic impact on the fishery to be minimal. Data collected onboard Spanish longliners fishing in the Azores also indicate that the frequency of cetacean depredation is low $(3.6 \%$ of depredated sets) and responsible for less than 1\% of fish loss per trip (Hernandez-Milian et al., 2008). False killer whales were considered responsible for all depredation occurrences in the Azores (Hernandez-Milian et al., 2008).

Trawl nets are responsible for taking large numbers of cetaceans and pinnipeds (Northridge, 1991; Hall et al., 2000). In the Azores, trawling is prohibited because it is regarded as a poorly selective fishing method that has high negative impacts on fish stocks and on marine habitats (Probert et al., 2007). In 2001, the Regional Government of the Azores decided to open an exception and allowed a trawler from New Zealand to carry out a fishing experiment to assess the economic viability of a fishery for orange roughy in the region. The boat reached the fishing quota in only a few sets and the experiment was halted; there are no plans to resume it in the near future. No cetaceans were captured during the experiment. In 2005 a new EC regulation was published prohibiting the use of bottom trawls and any towed nets that operate close to the bottom (Probert et al., 2007, Santos et al., 2009). 
It is very unlikely that any of the deep-sea fisheries examined pose a significant threat to cetaceans or is negatively affected by cetaceans. Nonetheless, it is of the utmost importance that POPA continues monitoring these fisheries to collect information on fishing operations and bycatch.

This study suggests that levels of interaction between cetaceans and Azorean fisheries are generally low and that the economic impact of cetacean interference in most fisheries is small. However, it should be stressed that levels of observer coverage for the demersal and swordfish fisheries were low and rates of interaction reported here may be underestimated. Also, this study did not take into account fishing operations of Portuguese and Spanish vessels fishing for swordfish in Azorean waters, meaning that data on fishing effort and cetacean interaction presented here should not be extrapolated to those fleets.

Incidental mortality of cetaceans in Azorean fisheries seems insignificant and will hardly represent a threat for any of the species. Although detailed information on cetacean interactions is lacking for several fisheries, we do not anticipate significant levels of cetacean mortality in any of the cases. As mentioned earlier, these are mainly small-scale fisheries developed with traditional fishing gear that are unlikely to be responsible for catching cetaceans. On the other hand, several of the gear types known to cause significant cetacean bycatch, such as purse seine nets for tuna, trammel nets, drift gillnets, driftnets, bottom trawling and other deep-sea nets, are banned in the Azores. In spite of this, it is essential to collect information on cetacean interactions with these small-scale fisheries, through on-board observer programmes. In addition, existing programmes should be expanded to increase observation effort of some 
fisheries (e.g. demersal fisheries) and to allow monitoring of other fisheries (e.g. the swordfish fishery).

\section{Acknowledgements}

We thank all the observers that collected information onboard fishing vessels. We are also grateful to the captains, crew members and shipowners of all the fishing vessels that participate in observer programmes, who not only allowed the placement of observers aboard their vessels but also provided very important pieces of information. We acknowledge the crucial work of the colleagues responsible for supervising the observer's work and data collection. We thank the Azorean Regional Government and project ORPAM (Interreg IIIB-MAC) for funding POPA and the Shipowners Proprietors and the Association of the Tuna Canning Industries for their support to the programme. The Sea Turtle Monitoring Programme was funded by US National Marine Fisheries Service (US Department of Commerce, National Oceanic and Atmospheric Administration) contracts to the Archie Carr Center for Sea Turtle Research at the University of Florida: Phase 1 (2000, NA96FE0393), Phase 2 (2001, NA16FM1378), Phase 3 (2002, NA16FM2589), Phase 4 (2003, NA03NMF4540204), Phase 5 (2004, NA04NMF4540318). We are grateful to Mark Baumgartner and one anonymous reviewer for their comments on an earlier draft of this paper and to Ricardo Medeiros for providing the map of the Azorean EEZ. M.A.S. was supported by an FCT postdoctoral (SFRH/BPD/29841/2006) grant, and R.P. was supported by an FCT doctoral grant (SFRH/BD/32520/2006). IMAR- DOP/UAç is the R\&D Unit \#531 and part of the Associated Laboratory ISR funded through the Pluri-annual and Programmatic funding schemes of FCT-MCTES and DRCT-Azores. 


\section{References}

Allen RL. 1985. Dolphins and the purse-seine fishery for yellowfin tuna. In Marine Mammals and fisheries. Beddington JR, Beverton RJH, Lavigne DM (eds). George Allen and Unwin: London; 236-252.

Beddington JR, Beverton RJH, Lavigne DM. 1985. Marine Mammals and Fisheries. George Allen \& Unwin: London.

Bolten AB, Martins HR, Bjorndal KA. 2000. Workshop to design an experiment to determine the effects of longline gear modification on sea turtle bycatch rates. NOAA Technical Memorandum NMFS-OPR 19. The National Oceanic and Atmospheric Administration, US Department of Commerce: Florida, US.

Brotons JM, Grau AM, Rendell L. 2008. Estimating the impact of interactions between bottlenose dolphins and artisanal fisheries around the Balearic Islands. Marine Mammal Science 24: 112-127.

Catarino R. 2006. Capturas acessórias da frota demersal de palangre de fundo dos Açores. BSc Thesis, Universidade do Algarve.

Cochran WG. 1977. Sampling techniques. John Wiley and Sons Inc: New York. Constantino E. 2006. Rejeições na pesca de demersais com palangre de fundo no Arquipélago dos Açores. BSc Thesis, Escola Superior de Tecnologia do Mar, Instituto Politécnico de Leiria.

Dalla Rosa L, Secchi ER. 2007. Killer whale (Orcinus orca) interactions with the tuna and swordfish longline fishery off southern and south-eastern Brazil: a comparison with shark interactions. Journal of the Marine Biological Association of the United Kingdom 87: 135-140. 
Dâmaso C. 2007. Interacção de cetáceos na pescaria de atum com arte de saltoe-vara do arquipélago dos açores. MSc Thesis, Universidade dos Açores.

Ferreira RL, Martins HR, Bolten AB, Santos MA, Erzini K, 2010. Influence of environmental and fishery parameters on loggerhead sea turtle by-catch in the longline fishery in the Azores archipelago and implications for conservation. Journal of the Marine Biological Association of the United Kingdom. doi:10.1017/S0025315410000846

Garrison LP. 2007. Interactions between marine mammals and pelagic longline fishing gear in the U.S. Atlantic Ocean between 1992 and 2004. Fishery Bulletin 105: $408-417$.

Hall MA, Alverson DL, Metuzals KI. 2000. By-catch: problems and solutions. Marine Pollution Bulletin 41: 204-219.

Hernandez-Milian G, Goetz S, Varela-Dopico C, Rodriguez-Gutierrez J, Romón-Olea J, Fuertes-Gamundi JR, Ulloa-Alonso E, Tregenza NJC, Smerdon A, Otero MG, Tato V, Wang J, Santos MB, López A, Lago R, Portela JM, Pierce GJ. 2008. Results of a short study of interactions of cetaceans and longline fisheries in Atlantic waters: environmental correlates of catches and depredation events. Hydrobiologia 612: $251-268$.

INE. 2007. Estatísticas da Pesca 2006. Instituto Nacional de Estatística, Direcção-Geral das Pescas e Aquicultura: Portugal.

Kaschner K, Watson R, Christensen V, Trites A, Pauly D. 2001. Modeling and mapping trophic overlap between marine mammals and commercial fisheries in the North Atlantic. In Fisheries impacts on North Atlantic Ecosystems: catch, effort and 
national/regional data sets. Zeller D, Watson R, Pitcher T, Pauly D (eds). Fisheries Center Research Reports 93. University of British Columbia: Canada; 35-45.

Machete M, Santos RS. 2007. Azores Fisheries Observer Program (POPA): A case study of the multidisciplinary use of observer data. In Proceedings of the 5th International Fisheries Observer Conference Victoria, British Columbia: Canada, 1518 May 2007; 114-116.

Machete M, Morato T, Menezes G. 2010. Experimental fisheries for black scabbardfish (Aphanopus carbo) in the Azores, Northeast Atlantic. ICES Journal of Marine Science. doi:10.1093/icesjms/fsq087

Martins, JA. 1986. Potencialidades da ZEE Açoriana. Relatório da VI Semana das Pescas dos Açores 6: 125-132.

Melo O, Menezes G. 2002. Projecto de acompanhamento da experiência de pesca dirigida ao peixe-relógio (Hoplostethus atlanticus) - FISHOR. Arquivos do DOP, Série Estudos 4/2002. Departamento de Oceanografia e Pescas, Universidade dos Açores: Portugal.

Menezes GM. 1996. Interacções tecnológicas na Pesca Demersal dos Açores. Arquivos do DOP, Série Estudos 1/1996. Departamento de Oceanografia e Pescas, Universidade dos Açores: Portugal.

Menezes G. 2003. Demersal Fish Assemblages in the Atlantic Archipelagos of the Azores, Madeira, and Cape Verde. PhD Thesis, Universidade dos Açores.

Menezes G, Pinho MR, Tempera F. 2002. Notas sobre possíveis impactos da abertura da ZEE dos Açores de acordo com a nova Política Comum das Pescas (PCP). Arquivos do DOP, Série Estudos 3/2002. Departamento de Oceanografia e Pescas, Universidade dos Açores: Portugal. 
Morato T, Guénette S, Pitcher TJ. 2001. Fisheries of the Azores (Portugal), 1982-1999. In Fisheries impacts on North Atlantic Ecosystems: catch, effort and national/regional data sets. Zeller D, Watson R, Pitcher T, Pauly D (eds). Fisheries Center Research Reports 93. University of British Columbia: Canada; 214-220.

Morato T, Varkey DA, Dâmaso C, Machete M, Santos M, Prieto R, Santos RS, Pitcher TJ. 2008. Evidence of a seamount effect on aggregating visitors. Marine Ecology Progress Series 357: 23-32.

Northridge SP. 1991. An updated world review of interactions between marine mammals and fisheries. Food and Agriculture Organization Fisheries Technical Paper 251. Food and Agriculture Organization of the United Nations: Rome.

Pinho MR. 2003. Abundance estimation and management of Azorean demersal species. PhD Thesis, Universidade dos Açores.

Pinho MR, Pereira JG, Rosa IS. 1995. Caracterização da pesca do isco vivo da frota atuneira açoreana. Arquivos do DOP, Série Estudos 2/95. Departamento de Oceanografia e Pescas, Universidade dos Açores: Portugal.

Prieto R, Pinho MR, Silva MA, Magalhães S. 2005. Dolphin interactions with hand line demersal fisheries in the Azores. In European Research on Cetaceans, Proceedings of the 19th Annual Conference of the European Cetacean Society: La Rochelle, France.

Probert PK, Christiansen S, Gjerde KM, Gubbay S, Santos RS. 2007. Management and conservation of seamounts. In Seamounts: Ecology, Fisheries and Conservation. Pitcher TJ, Morato T, Hart PJB, Clark MR, Haggan N, Santos RS (eds). Blackwell Publishing: Oxford, UK; 444-477. 
Read AJ. 1996. Incidental catches of small cetaceans. In The conservation of whales and dolphins. Simmonds MP, Hutchinson JD (eds). John Wiley \& Sons Ltd: Chichester, UK; 109-128.

Read AJ. 2008. The looming crisis: interactions between Marine mammals and fisheries. Journal of Mammalogy 89: 541-548.

Roche C, Gasco N, Duhamel G, Guinet C. 2007. Marine mammals and demersal longlines fishery interactions in Crozet and Kerguelen Exclusive Economic Zones: an assessment of the depredation level. Convention on the Conservation of Antarctic Marine Living Resources Science 14:67-82.

Santos RS, Hawkins S, Monteiro LR, Alves M, Isidro EJ. 1995. Case studies and reviews: Marine research, resources and conservation in the Azores. Aquatic Conservation: Marine and Freshwater Ecosystems 5: 311-354.

Santos RS, Christiansen S, Christiansen B, Gubbay S. 2009. Toward the conservation and management of Sedlo Seamount: A case study. Deep-Sea Research Part II 56: 2720-2730.

Silva AA. 2000. The swordfish fishery in the Azores: an overview. In Workshop to design an experiment to determine the effects of logline gear modification on sea turtle bycatch rates. Bolten AB, Martins HR, Bjorndal KA (eds). NOAA Technical Memorandum NMFS-OPR 19. The National Oceanic and Atmospheric Administration, US Department of Commerce: Florida, US; 3-16.

Silva MA, Feio R, Prieto R, Gonçalves JM., Santos RS. 2002. Interactions between cetaceans and the tuna fishery on the Azores. Marine Mammal Science 18: 893-901. 
Silva MA, Prieto R, Magalhães S, Cabecinhas R, Cruz A, Gonçalves JM, Santos RS. 2003. Occurrence and distribution of cetaceans in the waters around the Azores (Portugal), Summer and Autumn 1999-2000. Aquatic Mammals 29: 77-83.

Simões PR. 1995. The swordfish (Xiphias gladius L. 1758) fishery in the Azores, from 1987 to 1993. ICCAT-International Commission for the Conservation of Atlantic Tunas. Collective volume of scientific papers 44: 126-131.

Trites AW, Christensen V, Pauly D. 1997. Competition between fisheries and marine mammals for prey and primary production in the Pacific Ocean. Journal of Northwest Atlantic Fishery Science 22: 173-187.

Wada K, Hayama S, Nakaoka T, Uno H. 1991. Interactions between Kuril seals and salmon trap nets in the coastal waters of Southeastern Hokkaido. Marine Mammal Science 7: 75-84.

Wickens P. 1994. Interactions between South African fur seals and the purseseine fishery. Marine Mammal Science 10: 442-457.

Wise L, Silva A, Ferreira M, Silva MA, Sequeira M. 2007. Interactions between small cetaceans and the purse-seine fishery in western Portuguese waters. Scientia Marina 71: 405-412. 


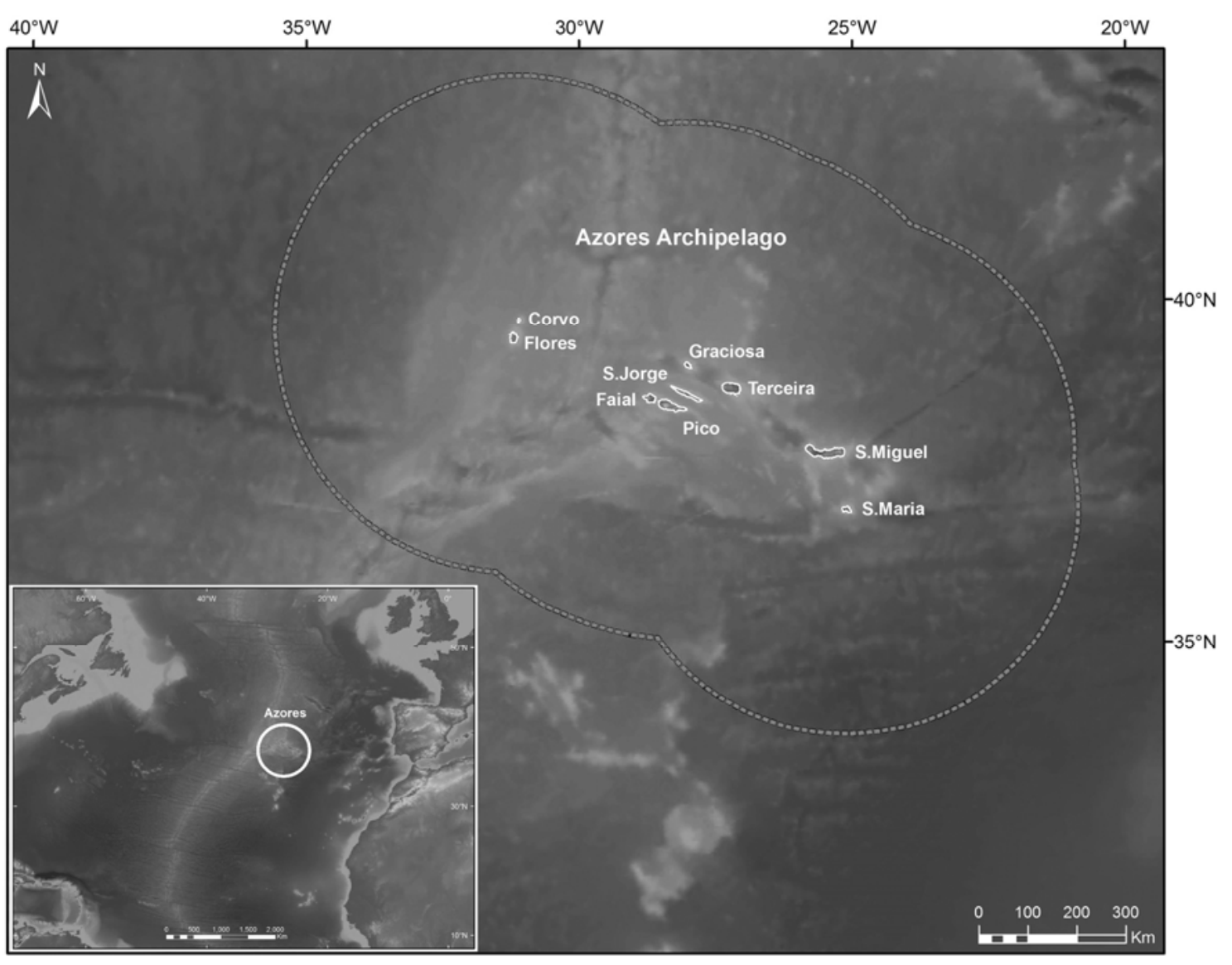

Figure 1. Location of the Archipelago of the Azores in the North Atlantic. The Exclusive Economic Zone of the Azores is delimitated by the dashed line. 


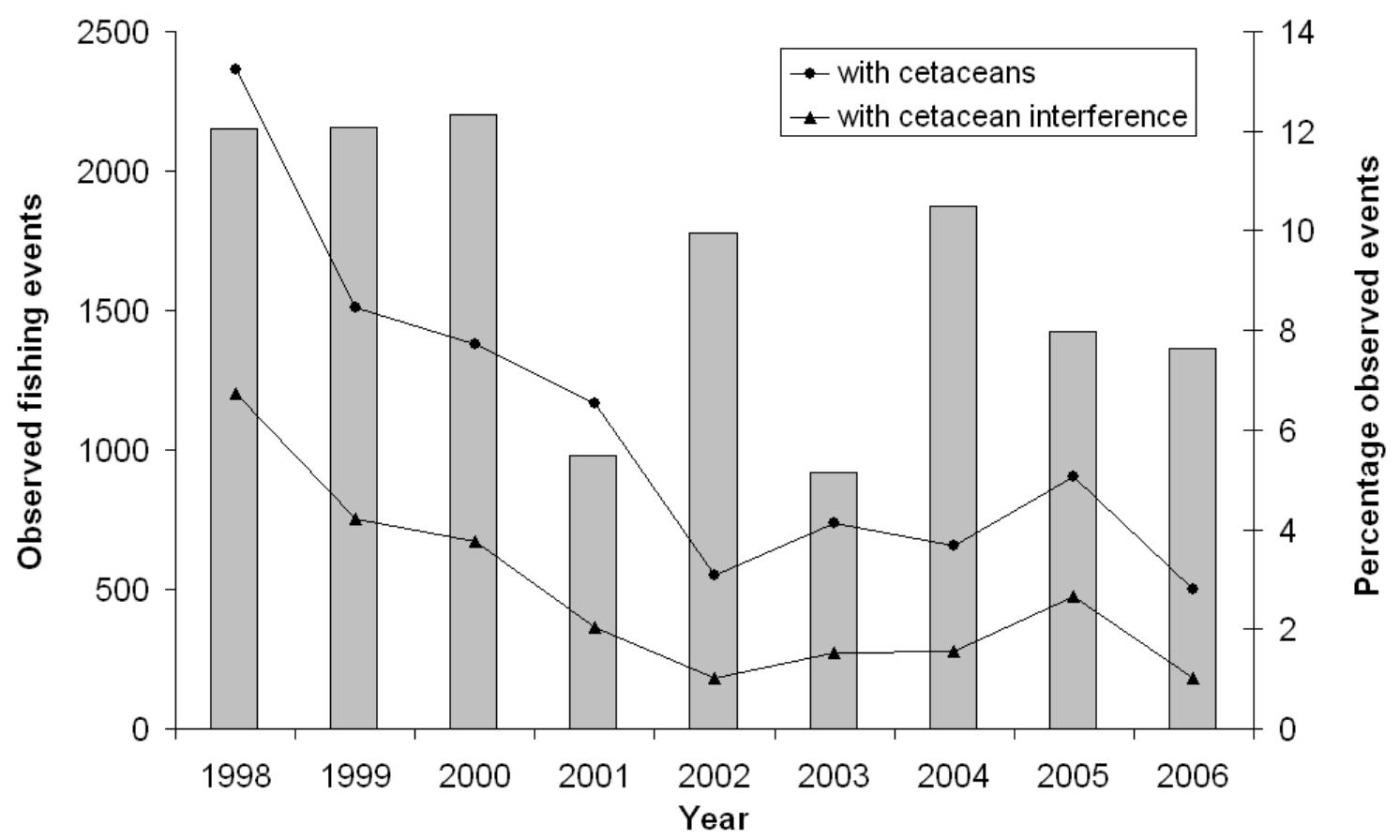

Figure 2. Number of fishing events observed and percentage of events in which 779 cetaceans were present or interfered with the tuna fishery, from 1998 to 2006. 


\begin{tabular}{|c|c|c|c|c|c|}
\hline \multirow{2}{*}{ Fishery } & \multirow{2}{*}{ Gear } & \multicolumn{2}{|c|}{ Monitoring } & \multirow{2}{*}{ Fishing effort } & \multirow{2}{*}{$\begin{array}{l}\text { Verified or } \\
\text { potential } \\
\text { cetacean } \\
\text { interference }\end{array}$} \\
\hline & & Programme & Period & & \\
\hline Tuna & $\begin{array}{l}\text { Pole and } \\
\text { line }\end{array}$ & POPA & $\begin{array}{l}\text { Apr-Oct, } \\
\text { 1998-2006 }\end{array}$ & $\begin{array}{l}\text { Annual landings } \\
\text { of the fleet }\end{array}$ & $\begin{array}{l}\text { Tuna } \\
\text { sink/cetaceans } \\
\text { feed live } \\
\text { bait/both }\end{array}$ \\
\hline $\begin{array}{l}\text { Small } \\
\text { pelagics }\end{array}$ & $\begin{array}{l}\text { Small } \\
\text { purse-seine }\end{array}$ & POPA & $\begin{array}{l}\text { Apr-Oct, } \\
\text { 1998-2006 }\end{array}$ & $\begin{array}{l}\text { No available } \\
\text { data }\end{array}$ & $\begin{array}{l}\text { Fish } \\
\text { sink/cetaceans } \\
\text { feed fish/both }\end{array}$ \\
\hline Demersal & $\begin{array}{l}\text { Handlines, } \\
\text { Bottom } \\
\text { longline }\end{array}$ & NPCD & $\begin{array}{l}\text { Nov-Dec } \\
2004, \\
\text { Aug-Dec } \\
2005 \text {, } \\
\text { Sep-Dec } 2006\end{array}$ & $\begin{array}{l}\text { Annual landings } \\
\text { of the fleet }\end{array}$ & Depredation \\
\hline Demersal & $\begin{array}{l}\text { Bottom } \\
\text { longline }\end{array}$ & $\begin{array}{l}\text { Catarino } \\
(2006)\end{array}$ & $\begin{array}{l}\text { Aug-Sep } \\
2004\end{array}$ & $\begin{array}{l}\text { Annual landings } \\
\text { of the fleet }\end{array}$ & Depredation \\
\hline Demersal & Handlines & $\begin{array}{l}\text { Prieto et al. } \\
(2005)\end{array}$ & $\begin{array}{l}\text { May } \\
2002-\text { Aug } \\
2004\end{array}$ & $\begin{array}{l}\text { Annual landings } \\
\text { of the fleet }\end{array}$ & $\begin{array}{l}\text { Removal and } \\
\text { depredation }\end{array}$ \\
\hline Swordfish & $\begin{array}{l}\text { Surface } \\
\text { longline }\end{array}$ & $\begin{array}{l}\text { Turtle } \\
\text { Programme }\end{array}$ & $\begin{array}{l}1998, \\
2000-2004\end{array}$ & $\begin{array}{l}\text { Estimated } \mathrm{n}^{\mathrm{o}} \\
\text { sets and hooks } \\
\text { deployed per } \\
\text { year by the fleet }\end{array}$ & Depredation \\
\hline $\begin{array}{l}\text { Black } \\
\text { scabbard } \\
\text { fish }\end{array}$ & $\begin{array}{l}\text { Drifting } \\
\text { bottom } \\
\text { longline }\end{array}$ & POPA & 1999-2005 & $\begin{array}{l}\text { No available } \\
\text { data }\end{array}$ & Depredation \\
\hline $\begin{array}{l}\text { Orange } \\
\text { roughy }\end{array}$ & Trawl & $\begin{array}{l}\text { Melo and } \\
\text { Menezes } \\
(2002)\end{array}$ & $\begin{array}{l}\text { Apr-Jun 2001, } \\
\text { Dec 2001-Jan } \\
2002\end{array}$ & $\begin{array}{l}\text { Experimental } \\
\text { fishery; } 246 \\
\text { hauls }\end{array}$ & $\begin{array}{l}\text { Interference not } \\
\text { observed }\end{array}$ \\
\hline $\begin{array}{l}\text { Deepwater } \\
\text { crab }\end{array}$ & Traps & POPA & $2003-2004$ & $\begin{array}{l}\text { Experimental } \\
\text { fishery; } 200 \text { sets }\end{array}$ & $\begin{array}{l}\text { Interference not } \\
\text { observed }\end{array}$ \\
\hline $\begin{array}{l}\text { Deepwater } \\
\text { pandalid } \\
\text { shrimp }\end{array}$ & Traps & POPA & $\begin{array}{l}\text { November } \\
2006\end{array}$ & $\begin{array}{l}\text { Experimental } \\
\text { fishery; } 23 \text { sets }\end{array}$ & $\begin{array}{l}\text { Interference not } \\
\text { observed }\end{array}$ \\
\hline
\end{tabular}
cetacean interference in each fishery monitored.$$
\text { cetacean interference in each fishery monitored. }
$$ 


\begin{tabular}{|c|c|c|c|c|c|c|c|}
\hline \multirow{2}{*}{ Year } & \multirow{2}{*}{$\begin{array}{c}\text { Total } \\
\text { landings } \\
\text { (t) }\end{array}$} & \multirow{2}{*}{$\begin{array}{l}\text { Observed } \\
\text { landings } \\
\text { (t) }\end{array}$} & \multirow{2}{*}{$\begin{array}{l}\text { Observer } \\
\text { coverage }\end{array}$} & \multicolumn{2}{|c|}{$\begin{array}{l}\text { Observed } \\
\text { captures }\end{array}$} & \multicolumn{2}{|c|}{ Estimated captures } \\
\hline & & & & Number & $\begin{array}{l}\text { Capture } \\
\text { rate }\end{array}$ & Number & $95 \% \mathrm{CI}$ \\
\hline 1998 & 5,400 & 2,133 & 39.5 & 15 & 0.0070 & 38.0 & $16.91-59.06$ \\
\hline 1999 & 2,153 & 1,444 & 67.1 & 25 & 0.0173 & 37.3 & $22.78-51.79$ \\
\hline 2000 & 1,512 & 852 & 56.4 & 9 & 0.0105 & 16.0 & $11.74-20.19$ \\
\hline 2001 & 1,135 & 536 & 47.2 & 1 & 0.0019 & 2.1 & $0.12-4.12$ \\
\hline 2002 & 1,467 & 665 & 45.3 & 1 & 0.0015 & 2.2 & $1.14-5.56$ \\
\hline 2003 & 2,890 & 1,051 & 32.0 & 0 & 0 & 0 & \\
\hline 2004 & 4,130 & 1,895 & 45.9 & 0 & 0 & 0 & \\
\hline 2005 & 2,428 & 1,274 & 52.5 & 6 & 0.0047 & 11.4 & $2.71-20.17$ \\
\hline 2006 & 4,828 & 2,559 & 53.0 & 2 & 0.0008 & 3.4 & $1.25-6.29$ \\
\hline Total & 25,943 & 12,409 & 47.8 & 59 & 0.0046 & & \\
\hline
\end{tabular}

Table 2. Total and observed landings, observer coverage (percentage of observed tonnage of tuna landed in relation to total landings), number of cetaceans captured, capture rate (ratio of cetaceans caught per observed tonnage of tuna landed) and estimated number of cetaceans captured and $95 \%$ confidence intervals $(\mathrm{CI})$, for the tuna fishery, 1998 to 2006. Data for the period 1998-2000 were taken from Silva et al. (2002).
792

793 
Table 3. Percentage of interference of each cetacean species in the fisheries monitored.

\begin{tabular}{lcccccc}
\hline & \multicolumn{7}{c}{ Interference (\%) with the fishery } \\
Cetacean species & Tuna & $\begin{array}{c}\text { Small } \\
\text { pelagics }\end{array}$ & $\begin{array}{c}\text { Demersal } \\
\text { (NPCD) }\end{array}$ & $\begin{array}{c}\text { Demersal } \\
\text { (Catarino } \\
\text { (2006) }\end{array}$ & $\begin{array}{c}\text { Demersal } \\
\text { (Prieto } \text { et } \\
\text { al., 2005) }\end{array}$ & Swordfish \\
\hline Delphinus delphis & 73 & 58 & --- & --- & 33 & --- \\
Stenella frontalis & 16 & 5 & --- & --- & --- & --- \\
Tursiops truncatus & 10 & 5 & 100 & 100 & 66 & --- \\
Grampus griseus & 0.15 & --- & --- & --- & --- & --- \\
Pseudorca crassidens & 0.15 & --- & --- & --- & --- & --- \\
Orcinus orca & --- & --- & --- & --- & --- & 33 \\
Mesoplodon sp. & 0.15 & --- & --- & --- & --- & --- \\
Balaenoptera acutorostrata & 0.10 & --- & --- & --- & --- & --- \\
Unidentified & 0.45 & 32 & --- & --- & --- & 66 \\
\hline
\end{tabular}

802

803

Table 4. Total landings, observed landings and observer coverage (percentage of observed tonnage of fish landed in relation to total landings) for demersal fisheries, 2004 to 2006.

\begin{tabular}{cccc}
\hline Year & Total landings $(\mathrm{t})$ & Observed landings $(\mathrm{t})$ & Observer coverage \\
\hline 2004 & 3,400 & 33.2 & 1.0 \\
2005 & 3,913 & 11.3 & 0.3 \\
2006 & 3,410 & 15.2 & 0.4 \\
Total & 10,723 & 59.7 & 0.6 \\
\hline
\end{tabular}


Table 5. Number of observed trips, sets and hooks, and presence and interference of cetaceans in demersal fisheries, 2004 to 2006.

\begin{tabular}{lcccccc}
\hline \multirow{2}{*}{ Year } & Months & Trips & Sets & Hooks & \multicolumn{2}{c}{ Sets with cetaceans } \\
\cline { 5 - 7 } & & & & Presence (\%) & Interference(\%) \\
\hline 2004 & November-December & 23 & 89 & 7773 & $41(46.1)$ & $22(24.7)$ \\
2005 & August-December & 25 & 124 & 9057 & $32(26.4)$ & $19(15.7)$ \\
2006 & September-December & 20 & 58 & 5167 & $10(17.2)$ & $1(1.7)$ \\
Total & & & & & $83(31.0)$ & $42(15.7)$ \\
\hline
\end{tabular}

814

\begin{tabular}{lccccc}
\hline \multirow{2}{*}{ Year } & Months & Sets & Hooks & \multicolumn{2}{c}{ Sets with cetaceans } \\
\cline { 5 - 6 } & & & & Presence (\%) & Interference(\%) \\
\hline 1998 & April-August & 41 & 88420 & $0(0)$ & $0(0)$ \\
2000 & July-December & 93 & 138121 & $10(10.8)$ & $0(0)$ \\
2001 & September-December & 60 & 88150 & $4(6.7)$ & $0(0)$ \\
2002 & September-December & 48 & 75511 & $1(2.1)$ & $1(2.1)$ \\
2003 & September-December & 73 & 114417 & $1(1.4)$ & $1(1.4)$ \\
2004 & September-December & 69 & 81681 & $4(5.8)$ & $1(1.4)$ \\
Total & & 384 & 586300 & $20(5.2)$ & $3(0.8)$ \\
\hline
\end{tabular}

Table 6. Observed sets and hooks, and presence and interference of cetaceans in the swordfish fishery from 1998 to 2004. 